\title{
The Determinants of Chinese Property Prices
}

\author{
Ming Qi ${ }^{1}$ \\ ${ }^{1}$ School of Business Administration, China University of Petroleum (Beijing), China \\ Correspondence: Ming Qi, School of Business Administration, China University of Petroleum (Beijing), China. \\ E-mail: qiming@cup.edu.cn
}

Received: July 9, 2016

Accepted: July 29, 2016

Online Published: December 20, 2016

doi:10.5539/ijef.v9n1p194

URL: http://dx.doi.org/10.5539/ijef.v9n1p194

\begin{abstract}
In this paper, the determinants the housing prices boom in China are investigated. We extend the original model of Yuan and Xiao and Zhou (2006) by involving banks, in order to investigate the behavior of the money lender. A sample of 28 Chinese domestic commercial banks during the period between 2003 and 2009 are used for the empirical test. The results suggest that the mortgage loan has a significant impact on the property prices. Their effects on both condominium and residential prices are positive. However, the prices of High_Grade and Economical Houses have shown an entirely different response to the movement of mortgage credits.
\end{abstract}

Keywords: mortgage, house price, banks, interest rate, CPI

\section{Introduction}

The past decade has witnessed an overall boom of home price growth in both new and existing markets with first- and selected second-tier cities in China. The soaring property prices have been extensively documented in China. China provides a representative figure of emerging property market which experienced the soaring property prices. Figure 1 illustrates the movements of mortgage loans and property prices. In a recent survey of 70 cities by the National Bureau of Statistics (NBS), 51 reported price gains in new houses. The surge of property prices can be attributed to both monetary and financial policies in China (Yu 2010). House stock is also regarded as the response to the land-use regulation through the elasticity of new housing supply. (Quigley \& Raphael, 2005).

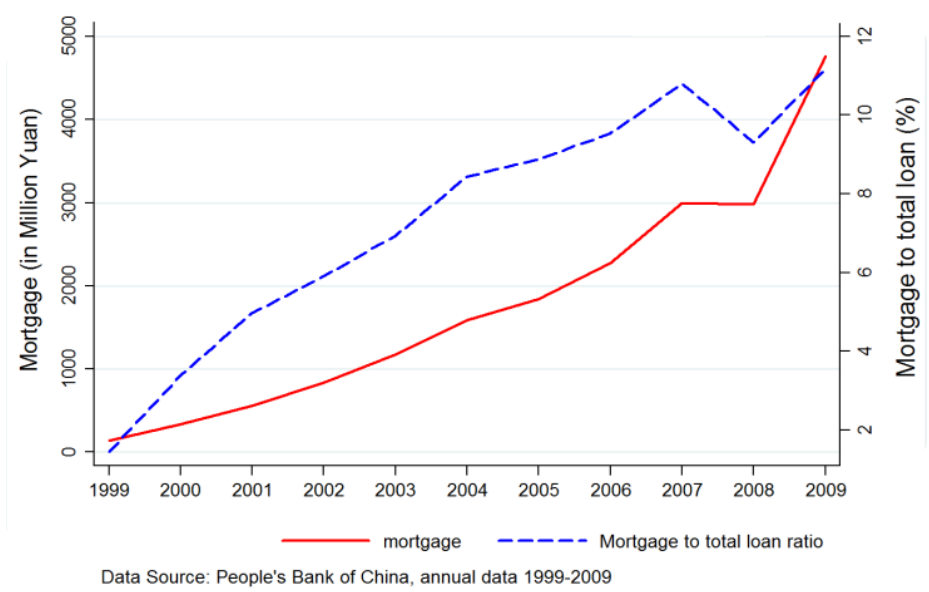

Figure 1. Mortgage outstanding and average property prices

The government authorized all the commercial banks to issue household mortgage in 1998. Commercial banks also recognize the residential mortgage credits as health assets in their portfolio given the lower default rate of loans to individual mortgagors than that to state-owned entrepreneurs. (Deng \& Fei, 2008). The mortgage boom has significantly contributed to the property price surge in China. (Zhang, 2000) In this paper we investigate what determinants the housing prices boom in China. National disposable income is the primary factor which has significant impact on the property prices (McQuinn \& O'Reilly, 2007, Hill \& Gan, 2008). On the other hand, 
China has witnessed a dramatic urbanization and industrialization process during the past decades (Zheng et al., 2007). More and more internal immigrants choose to settle down in cities. Their demand on houses is another significant accelerator to the housing prices surge. We test to what extend the bank's behaviors and monetary policies have impacts on the property sector. The interest rate is a typical indicator of monetary policy in estimating the property market. Real interest rate is more closely associated with property prices than with bank lending. Hofmann (2003), Wolswijk (2006) and Égertand and Mihaljek (2007) find the negative effect of interest rate on housing prices. A declining interest rate is benefit to the increasing demand for property investments. (Green \& Shoven, 1986; Kearl, 1979; Tsatsaronis \& Zhu, 2004; Wolswijk, 2006; Égertand \& Mihaljek, 2007). Figure 2 shows the movements of Required Reserve Ratio for banks and mortgage rates.

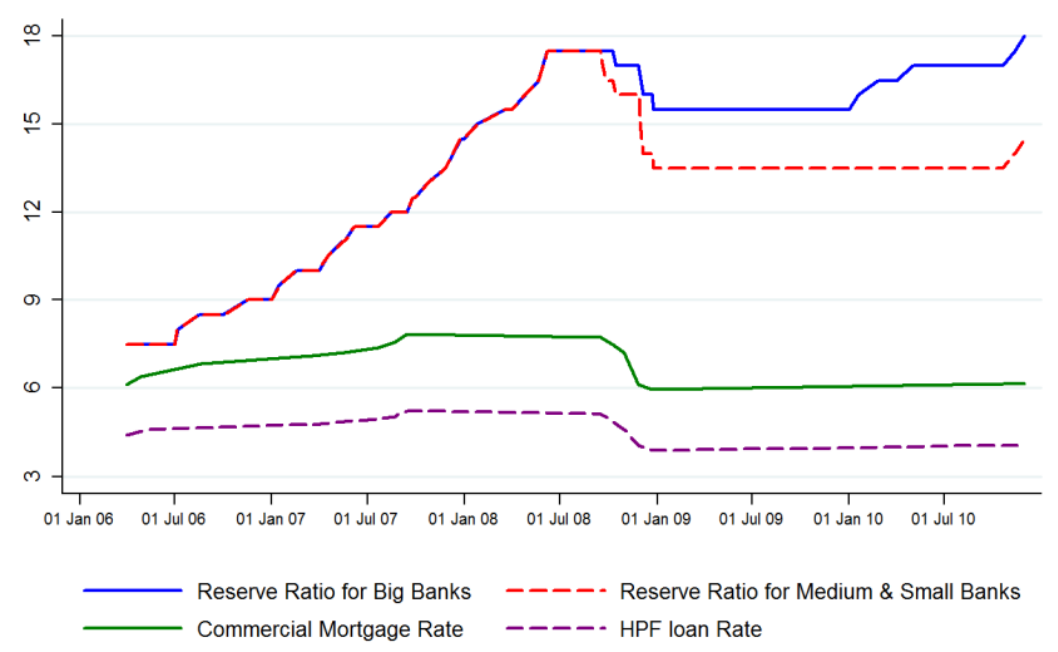

Data source: The People's Bank of China

Note: Big banks refer to five State-Owned banks and the Postal saving bank.

Figure 2. Movements of required reserve ratio for and mortgage rates

In terms of the property prices, we use four different housing prices to capture the dynamic of property market in China. They are condominium price, which is the average housing price; residential price, which is the index of solo residential market; high_grade houses price, which represents the luxury and high-end real estate market; and last economic houses price, which is the price of affordable houses. Figure 3 illustrates the movements of property prices in four separate real estate market. The paper is organized as follows. Section 2 reviews the literature on Chinese property market. Section 3 describes the data and methodology. The empirical results are presented in section 4 . Section 5 concludes this paper.

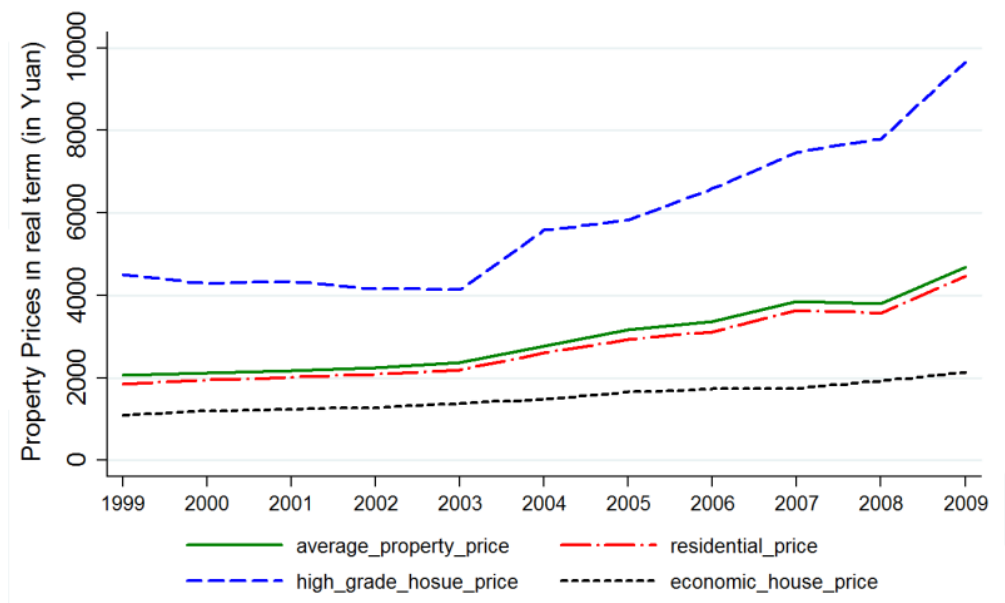

Data source: Nationa Bureau of Statistics of China. Note: Property prices are in real term.

Figure 3. Movements of property prices 


\section{Literature Review}

Various theoretical models and empirical frameworks have been proposed to explain what determines the property price movements in China. Wu et al. (2016) investigates the Chinese property market from the perspective of supply and demand conditions. The results imply that there is strong positive trend in house price and land value in China. Zhang et al. (2015) introduces the house searching model with down-payment constraints. They find strong Granger relationship in coastal cities where house prices are high with speculation, but weak relationship in inland cities where speculative activity is relatively weak. Market intervention have some impacts but cannot affects the market power as a whole. On the other hand, several cross-country evidence have indicated that the property have close relationship with mortgage lending (Égert \& Mihaljek, 2007; Lacoviello \& Minetti, 2008; Goodhart \& Hofmann, 2008; Davis \& Zhu, 2010). Capozza et al. (2002), Gimeno and Martinez-Carrascal (2006); and Fitzpatrick and McQuinn (2007) investigate the case of USA, Spain and Irland respectively and reach the same conclusion. Liang and Cao (2007) find a unidirectional causality from bank lending, interest rate and income to property prices in China. Some researches also confirm the significant impact of household income on housing prices (Jud \& Winkler, 2002; Gimeno \& Martinez-Carrascal, 2006; Bourassa et al., 2006). Nevertheless, some researches find little impact of household income on housing prices. (Tsatsaronis \& Zhu, 2004) Zhang et al. (2012) use the Nonlinear Auto Regressive Moving Average with eXogenous inputs (NARMAX) to investigate determinants of housing prices in China. The findings suggest that mortgage rate, producer price, broad money supply and real effective exchange rate and price variables can be used to explain the housing price dynamics in China. Two alternative models have been proposed to explain the housing prices movements in the literature. Muellbauer and Murphy (1997 and Meen (2002) suggest the inverted demand model which involves the housing supply and credit conditioning. The alternative one is house price-to-rent model, which is proposed by Ayuso and Restoy (2006). In this model, the arbitrage between owned and rental houses are investigated. Wu et al. (2014) suggests that the simple average method cannot explain the substantial complex-level dynamics in Chinese housing market. They apply a hedonic method to 35 major newly-built housing markets and provide the first multi-city constant-quality house price index in China.

\section{Data Description and Methodology}

\subsection{Methodology}

We firstly propose a theoretical model to understand both borrowers' and banks' behavior. This model is an extension of Yuan and Xiao (2003) and Zhou (2006). The bank is involved in this modified model, in order to investigate the behavior of the money lender.

\subsubsection{Borrower's Behavior}

Assume there are two kinds of goods in the market - the house occupation and a composite consumption good. We use Cobb-Douglas utility function to analyze borrower's behavior:

$$
U=X^{\alpha} \cdot Y^{1-\alpha}
$$

Where $U$ denotes the utility of a borrower, $X$ is the consumption of a composite good; $Y$ is the house occupation of the household and $\alpha$ is the indicator of house purchase intension. Considering the monotonicity of utility function, we take logarithmic transformation of the utility function.

$$
\log U=\alpha \cdot \log X+(1-\alpha) \cdot \log Y
$$

Suppose the households use mortgage loans to finance the house occupation, and then use the dispensable income to support the consumption of house service and the composite good. We can maximize the borrower's utility under the constraint of dispensable income.

$$
\begin{gathered}
\max _{X, Y} \log U=\alpha \cdot \log X+(1-\alpha) \cdot \log Y \\
\text { s.t. } X+[1+(r-i)] \cdot M=I \\
M=P \cdot Y
\end{gathered}
$$

Where $I$ represent the dispensable income of borrowers, $r$ is the real interest rate of individual banks, $i$ denote the inflation rate, $M$ is the total mortgage loans, and $P$ is the house price. Optimal allocation is solved through the Lagrange function:

$$
L=\alpha \cdot \log X+(1-\alpha) \cdot \log Y-\lambda[X+(1+r-i) \cdot P \cdot Y-I]
$$

Thesis of the Lagrange function is shown as follows: 


$$
\left\{\begin{array}{l}
\frac{\partial L}{\partial X}=\frac{\alpha}{X}-\lambda=0 \\
\frac{\partial L}{\partial Y}=\frac{1-\alpha}{Y}-\lambda \cdot(1+r-i) \cdot P=0 \\
\frac{\partial L}{\partial \lambda}=X+(1+r-i) \cdot P \cdot Y-I=0
\end{array}\right.
$$

By solving the linear equation system above with three unknowns, which are $\mathrm{P}, \mathrm{M}$, and $\lambda$ respectively, we get:

$$
M=P \cdot Y=\frac{(1-\alpha) \cdot I}{(1+r-i)}
$$

It implies that the mortgage demand increases with borrower's income and house price, but decreases with the house purchase intension and the interest rate. In addition, the inflation rate has a positive impact on the mortgage demanding.

\subsubsection{Bank's Behavior}

We assume the whole deposits of banks are interest-bearing assets. They allocate a proportion of total deposits on the mortgage market. The total mortgage lending is denoted as $Y$, which is equal to consumers' demand of mortgage loans. The Loan_To_Deposit ratio is $\theta$. Then the mortgage lending can be rewritten as $Y=\theta \cdot D$. An individual bank earns the interest rate $r$ on its mortgage loans and pays out the interest rate $r^{d}$ for customers' deposits. The lending business incurs a cost $C$, which is a quadratic function of total mortgage loans, i.e. $C(Y)=c\left(1+Y^{2}\right)$. The individual bank aims to maximize its total profits, which is denoted as $\pi$. Then the maximization function of banks is proposed as follows:

$$
\begin{gathered}
\max \pi=r \cdot M-N \cdot c\left[1+Y^{2}\right]-r^{d} \cdot D \\
\text { s.t. } \quad M=N \cdot P \cdot Y \\
M=\theta \cdot D
\end{gathered}
$$

If we plug $M$ and $D$ into our target function, we get:

$$
\begin{gathered}
\max _{M} \pi=r \cdot M-N \cdot c\left[1+\left(\frac{M}{N \cdot P}\right)^{2}\right]-r^{d} \cdot \frac{M}{\theta} \\
\Leftrightarrow \frac{\partial \pi}{\partial M}=\left(r-\frac{r^{d}}{\theta}\right)-\frac{2 c N \cdot M}{(N \cdot P)^{2}}=0 \\
M=\frac{\left(r-r^{d} / \theta\right) \cdot N \cdot P}{2 c}
\end{gathered}
$$

then we replace the loan to deposit ratio $\theta$ by $Y / D$ and get:

$$
M=\frac{\left(r-\frac{r^{d}}{M / D}\right) \cdot N \cdot P^{2}}{2 c}=\frac{\left(r-\frac{r^{d} \cdot D}{M}\right) \cdot N \cdot P^{2}}{2 c}=\frac{\left(r \cdot M-r^{d} \cdot D\right) \cdot N \cdot P^{2}}{2 c M}=\frac{\frac{r \cdot M-r^{d} \cdot D}{D} \cdot N \cdot P^{2}}{2 c \frac{M}{D}}
$$

Now, we can find that $\frac{r \cdot M-r^{d} \cdot D}{D}$ is the net interest margin (NIM) of the individual bank, and the denominator is $2 c M / D=2 c \cdot \theta$. The optimal mortgage supply provided by the bank increases with its NIM, the number of mortgagers $(N)$, housing price $(P)$ but decrease with the Loan_To_Deposit ratio $(\theta)$.

\subsubsection{Econometric Approach}

Previous research also indicates that House price is rather an endogenous variable and driven by market factors including credit/mortgage rationing. We employ a simplified Inverted demand model, which was introduced by Muellbauer and Murphy (1997), to estimate the movements of housing price (Note 1).

$$
\begin{array}{r}
H S / P o p=f(I, \mu, D) \\
\mu=P\left(r+\delta-\dot{P}^{e} / P\right)
\end{array}
$$

Where $\mu$ is the real user cost of housing service; $P$ is the housing price and $P^{e} / P$ is the expected appreciation rate 
of housing price (Note 2). Muellbauer and Murphy (1997) pointed out that a proxy of mortgage rationing is often included in measuring the housing price. By substituting the user cost into the housing stock function and involving the proxy of credit conditions, we get the invert demand function to estimate the housing price.

$$
P=f\left(H S, \dot{P}^{e} / P, I, \text { credit_rationing }\right)
$$

Where $H S, P^{e} / P$ and $I$ represent the housing stock, housing price appreciation rate and the Income respectively. We employ the ratio of house price to house rental index as the measure of housing appreciation rate in our estimation. Although the down payment ratio is a good and popular index of credit rationing, the house financing system in China has not experienced a significant change of this ratio. However, the change of Mortgage can partially reflect the bank's credit rationing. The increase of mortgage loans is associated with loosened credit criteria and lower interest rate. Therefore, we employ the change of mortgage to measure banks' credit rationing. Taking into account the estimation of mortgage lending, we then form a simultaneous equation system to estimate the movements of mortgage loans and housing prices as follows. Considering the bank-level mortgage data, the panel data approach and two-stage least squares/Instrument variable method are employed for the estimation.

$$
\begin{aligned}
\text { House Price }_{i t}=\beta_{0}+\beta_{1} \text { Housing Stock }_{i t}+ & \beta_{2} \text { Mortgage }_{i t}+\beta_{3} \text { Interest Rate }_{i t}+\beta_{4} \text { CPI }_{i t}+\beta_{5} \text { Housing Appriciation }_{i t-1} \\
& +\beta_{6} \text { Required Reserves }_{i t-1}+\varepsilon_{i t}
\end{aligned}
$$

\subsection{Data Description}

We carefully select explanatory variables for the empirical analysis so as to ensure our estimation is robust to omitted variables. The macro data which is collected from the People's Bank of China and National Bureau of Statistics of China. Mortgage loans, bank specific variables and house prices are collected from ALMANAC OF CHINA'S FINANCE AND BANKING. The number of house sales is used to estimate the housing stocks. The ratio of house price index to rental index is used to measure the house prices appreciation, which reflects consumers' purchase intention. In order to capture the heterogeneity among banks, we use the ratio of the interest revenues over total interest bearing assets to estimate the interest rates for each individual bank. We use four different categories of housing prices: condominium price, residential price, high_grade price and economic price. Table 1 lists the summary statistics of variables.

Table 1. Summary statistics of variables

\begin{tabular}{lcccc}
\hline Variable & Mean & Std. Dev & Min & Max \\
\hline Income $(\log )$ & 9.58 & 0.32 & 8.60 & 10.27 \\
Interest $(\log )$ & 1.65 & 0.25 & 0.44 & 2.14 \\
Mortgage $(\log )$ & 10.13 & 2.17 & 4.59 & 13.68 \\
Condominium price(log) & 8.31 & 0.37 & 7.63 & 9.53 \\
Residential price $(\log )$ & 8.26 & 0.38 & 7.53 & 9.49 \\
High grade price $(\log )$ & 8.91 & 0.32 & 8.06 & 10.00 \\
Economical price $(\log )$ & 7.58 & 0.27 & 6.94 & 8.38 \\
\hline
\end{tabular}

\section{Results}

The determinants of housing prices are illustrated in Table 2. We find that the mortgage loan has a significant impact on the property prices. Their effects on both condominium and residential prices are positive. It implies the procyclical behavior of credits boom and condominium prices as a general. However, the prices of High_Grade and Economical Houses have shown an entirely different response to the movement of mortgage credits. The economic house in China is also referred to as the capped-price house. Its price is more administrative interference, rather not market-oriented. And the market of High_Grade houses is featured by the high demand rigidity. The movements of these two special property markets cannot meet the boom of mortgage credits. In spite of the little effect of raising reserve ratio, the interest rate moves negative to the condominium prices and plays an active role in restraining the housing prices. We do not find significant impact of Housing Stock, expected appreciation rate of housing price or inflation rate on the movements of housing prices. 
Table 2. Determinants of housing prices

\begin{tabular}{|c|c|c|c|c|}
\hline & (1) & (2) & (3) & (4) \\
\hline & Condominium & Residencial & High_Grade & Economical \\
\hline \multirow[t]{2}{*}{ Mortgage } & $0.814^{*}$ & $0.744 * *$ & $-1.608^{*}$ & $-0.361 * * *$ \\
\hline & (1.92) & $(2.54)$ & $(-1.92)$ & $(-3.43)$ \\
\hline \multirow[t]{2}{*}{ Income } & 0.554 & 0.414 & $2.154^{* *}$ & $1.016^{* * *}$ \\
\hline & $(0.97)$ & $(0.81)$ & (2.09) & (4.33) \\
\hline \multirow[t]{2}{*}{ Intere rate } & $-0.417 *$ & $-0.394 * *$ & 0.602 & $0.153^{* *}$ \\
\hline & $(-1.84)$ & $(-2.22)$ & (1.38) & $(2.25)$ \\
\hline \multirow[t]{2}{*}{ CPI } & 1.085 & 1.065 & $-6.148^{*}$ & $-2.812 * * *$ \\
\hline & $(0.66)$ & $(0.79)$ & $(-1.88)$ & $(-4.04)$ \\
\hline Housing & 0.351 & 0.120 & -2.223 & $-1.273^{*}$ \\
\hline appreciation & $(0.35)$ & $(0.14)$ & $(-1.31)$ & $(-1.73)$ \\
\hline Required & -0.199 & -0.129 & 0.285 & -0.0122 \\
\hline reserves & $(-0.95)$ & $(-0.75)$ & $(0.80)$ & $(-0.23)$ \\
\hline Housing Stock & -0.469 & - & - & - \\
\hline Condominium & $(-1.35)$ & - & - & - \\
\hline Housing Stock & - & -0.347 & - & - \\
\hline Residencial & - & $(-1.45)$ & - & - \\
\hline Housing Stock & - & - & 0.651 & - \\
\hline High_Grade & - & - & (1.63) & - \\
\hline Housing Stock & - & - & - & -0.0817 \\
\hline Economical & - & - & - & $(-1.21)$ \\
\hline$N$ & 78 & 78 & 78 & 73 \\
\hline
\end{tabular}

Note. $t$ statistics in parentheses: * $\mathrm{p}<0.10, * * \mathrm{p}<0.05, * * * \mathrm{p}<0.01$.

\section{Conclusion}

China's property market has experienced dynamic change during the past decades. In this paper, we extend Yuan and Xiao (2003) and Zhou (2006)'s model to involve the role of banks. The theoretical model implies that the mortgage demand increases with borrower's income and house price, but decreases with the house purchase intension and the interest rate. The inflation rate has a positive impact on the mortgage demanding. On the other hand, The optimal mortgage supply provided by the bank increases with its NIM, the number of mortgagers, housing price, but decrease with the Loan_To_Deposit ratio. Following Muellbauer and Murphy (1997)'s invert demand model, we propose the empirical framework. The results show that the mortgage lending has significant contributions to the housing price surge. The procyclical behavior of credits boom and condominium prices are documented in China. But the situation for High_Grade and Economical housing market is quite different. The interest rate moves negative to the condominium prices and plays an active role in restraining the housing prices. Therefore, the interest rate is the most useful monetary tool for policy makers to restrain the rocketing property prices in China.

\section{Acknowledgement}

This work was supported by Beijing Natural Science Foundation under Grant (9164034); Humanity and Social Science Youth Foundation of Ministry of Education in China (Project No. 13YJC790112); Science Foundation of China University of Petroleum, Beijing under Grant 2462013 YJRC009.

\section{References}

Ayuso, J., \& Restoy, F. (2006). House prices and rents: An equilibrium asset pricing approach. Journal of Empirical Finance, 13, 371-388. https://doi.org/10.1016/j.jempfin.2005.10.004

Bourassa, S. C., Hoesli, M., \& Sun, J. (2006). A simple alternative house price index method. Journal of Housing Economics, 15, 80-97. https://doi.org/10.1016/j.jhe.2006.03.001

Capozza, D., Hendershott, P., Mack, C., \& Mayer, C. (2002). Determinants of Real House Price Dynamics. NBER Working Paper No. W9262. https://doi.org/10.3386/w9262

Davis, E. P., \& Zhu, H. (2010). Bank lending and commercial property cycles: Somecross-country evidence. Journal of International Money and Finance, 30, 1-21. https://doi.org/10.1016/j.jimonfin.2010.06.005

Deng, Y., \& Fei, P. (2008). The Emerging Mortgage Markets in China. In D. Ben-Shahar, C. K. Y. Leung, \& S. E. Ong (Eds), Mortgage Markets Worldwide (pp. 1-33). Oxford, UK: Blackwell Publishing Ltd. https://doi.org/10.1002/9781444302301.ch1 
Égert, B., \& Mihaljek, D. (2007). Determinants of house prices in central and eastern Europe. Comparative Economic Studies, 49, 367-388. https://doi.org/10.1057/palgrave.ces.8100221

Fitzpatrick, T., \& McQuinn, K. (2007). House prices and mortgage credit: Empirical evidence for Ireland. Manchester School, 75, 82-103. https://doi.org/10.1111/j.1467-9957.2007.01004.x

Gimeno, R., \& Martinez-Carrascal, C. (2006). The Interaction between House Prices and Loans for House Purchase: The Spanish Case. Banco de Espana Research Paper, No. WP-0605. https://doi.org/10.2139/ssrn.901145

Goodhart, C., \& Hofmann, B. (2008). House prices, money, credit, and the macroeconomy. Oxford Review of Economic Policy, 24, 180-205. https://doi.org/10.1093/oxrep/grn009

Green, J., \& Shoven, J. (1986). The Effects of Interest Rates on Mortgage Prepayments. Journal of Money, Credit and Banking, 18, 41-59. https://doi.org/10.2307/1992319

Hill, R. J., \& Gan, Q. (2008). A New Perspective on the Relationship Between House Prices and Income. UNSW Australian School of Business Research Paper No. 2008 ECON 13. https://doi.org/10.2139/ssrn.1313073

Hofmann, B. (2003). Bank Lending and Property Prices: Some International Evidence. HKIMR Working Paper No. 22/2003. https://doi.org/10.2139/ssrn.1009079

Jud, G., Winkler, D., \& Sirmans, S. (2002). The impact of information technology on real estate licensee income. Journal of Real Estate Practice and Education, 5, 1-16.

Kearl, J. R. (1979). Inflation, Mortgage, and Housing. The Journal of Political Economy, 87, 1115-1138. https://doi.org/10.1086/260815

Lacoviello, M., \& Minetti, R. (2008). The credit channel of monetary policy: Evidence from the housing market. Journal of Macroeconomics, 30, 69-96. https://doi.org/10.1016/j.jmacro.2006.12.001

Liang, Q., \& Cao, H. (2007). Property prices and bank lending in China. Journal of Asian Economics, 18, 63-75. https://doi.org/10.1016/j.asieco.2006.12.013

McQuinn, K., \& O'Reilly, G. (2007). A Model of Cross-Country House Prices. Research Technical Papers from Central Bank \& Financial Services Authority of Ireland (CBFSAI), No 5/RT/07.

Meen, G. (2002). The time series behavior of house prices: A transatlantic divide? Journal of Housing Economics, 11, 1-23. https://doi.org/10.1006/jhec.2001.0307

Muellbauer, J., \& Murphy, A. (1997). Booms and Busts in the UK Housing Market. The Economic Journal, 107, 1701-1727. https://doi.org/10.1111/j.1468-0297.1997.tb00076.x

Quigley, J., \& Raphael, S. (2005). Regulation and the High Cost of Housing in California. The American Economic Review, 95, 323-328. https://doi.org/10.1257/000282805774670293

Tsatsaronis, K., \& Zhu, H. (2004). What drives housing price dynamics: cross country evidence. BIS Quarterly Review, March.

Wolswijk, G. (2006). Determinants of Mortgage Debt Growth in EU Countries. European Journal of Housing Policy, 6, 131-149. https://doi.org/10.1080/14616710600787627

Wu, J., Deng, Y., \& Liu, H. (2014). House price index construction in the nascent housing market: The case of China. The Journal of Real Estate Finance and Economics, 48(3), 522-545. https://doi.org/10.1007/s11146-013-9416-1

Wu, J., Gyourko, J., \& Deng, Y. (2016). Evaluating the risk of Chinese housing markets: What we know and what we need to know. China Economic Review, 39, 91-114. https://doi.org/10.1016/j.chieco.2016.03.008

Yu, H. (2010). China's house price: Affected by economic fundamentals or real estate policy? Frontiers of Economics in China, 5, 25-51. https://doi.org/10.1007/s11459-010-0002-7

Yuan, Z., \& Xiao, X. (2003). An Analysis of Rational Bubbles in the Real Asset Market. Economic Research Journal, 3, 34-43.

Zhang, L., Hui, E. C. M., \& Wen, H. (2015). Housing price-volume dynamics under the regulation policy: Difference between Chinese coastal and inland cities. Habitat International, 47, 29-40. https://doi.org/10.1016/j.habitatint.2015.01.003

Zhang, X. Q. (2000): The Restructuring of the Housing Finance System in Urban China. Cities, 17, 339-348. https://doi.org/10.1016/S0264-2751(00)00030-5 
Zhang, Y., Hua, X., \& Zhao, L. (2012). Exploring determinants of housing prices: A case study of Chinese $\begin{array}{lllll}\text { experience in } \quad \text { Economic } & \text { Modelling, } & \text { 29(6), }\end{array}$ https://doi.org/10.1016/j.econmod.2012.06.025

Zheng , L., Huang, Q., Lu, T., \& Zhou, W. (2007): The Process and Problems of Industrialization and Urbanization in China: The Status of the Tenth Five-Year Plan and Recommendations for the Eleventh Five-Year Plan. Chinese Economy, 40, 6-30. https://doi.org/10.2753/CES1097-1475400101

Zhou, J. (2006). Forming and Evolvement of Real Estate Bubble —An Explanation of Hypothesis Financial Supportive Excess. Finance \& Trade Economics, 5, 3-10.

\section{Notes}

Note 1. Dougherty and Order investigate the measurement of the housing cost through two alternative approaches. They deduct the capital cost by maximizing household utility or implicit rent of the landlord and come up with the same results.

Note 2. Murphy also pointed that the long-run price-to-rent ratio can be estimated by real user cost and loan-to-value ratio.

\section{Copyrights}

Copyright for this article is retained by the author(s), with first publication rights granted to the journal.

This is an open-access article distributed under the terms and conditions of the Creative Commons Attribution license (http://creativecommons.org/licenses/by/4.0/). 